\title{
Regional issues raised by sea-level rise and their policy implications
}

\author{
Robert J. Nicholls ${ }^{1, *}$, Nobuo Mimura² \\ ${ }^{1}$ M iddlesex University, Q ueensway, Enfield, London EN 3 4SF, United Kingdom \\ ${ }^{2}$ C enter for Water Environment Studies (C WES), I baraki University, 4-12-1 Nakanarusawa, H itachi, Ibaraki 316, J apan
}

\begin{abstract}
Global sea levels are rising and this change is expected to accelerate in the coming century due to anthropogenic global warming. Any rise in sea level promotes land loss, increased flooding and salinisation. The impacts of and possible responses to sea-level rise vary at the local and regional scale due to variation in local and regional factors. Policy responses to the human-enhanced greenhouse effect need to address these different dimensions of climate change, including the regional scale. Based on global reviews and analyses of relative vulnerability, 4 contrasting regions are selected and examined in more detail using local and national assessments. These regions are (1) Europe, (2) West Africa, (3) South, South-East and East Asia and (4) the Pacific Small Islands. Some potential impacts of sea-level rise are found to have strong regional dimensions and regional cooperation to foster mitigation approaches (to reduce greenhouse gas emissions and, hence, the magnitude of climate change) and adaptive solutions to climate change impacts would be beneficial. For instance, in South, SouthEast and East Asia subsiding megacities and questions about long-term deltaic management are common and challenging issues. The debate on mitigation and stabilisation of greenhouse forcing also requires information on regional impacts of different emission pathways. These results will be provided by integrated models, calibrated against national assessments.
\end{abstract}

KEY WORDS: Sea-level rise $\cdot$ Climate change $\cdot$ Regions $\cdot$ Policy $\cdot$ Vulnerability assessment

\section{INTRODUCTION}

Humanity is preferentially concentrated in the coastal zones of the world. At least 200 million people were estimated to live in the coastal fLood plain (below the 1 in $1000 \mathrm{yr}$ storm surge) in 1990 (Hoozemans et al. 1993). This is likely to increase to at least 600 million people by 2100 (6\% of global population) as coastal populations are presently growing at twice the rate of global population increase (WCC'93 1994). Urbanisation and the rapid growth of large coastal cities is another fundamental change (Nicholls 1995a). Collectively, this is placing growing demands on coastal resources and increasing exposure to coastal hazards such as erosion and flooding. Global climate change, particularly sea-level rise, will exacerbate all these ongoing problems and its potential implications are causing concern (Bijlsma et al. 1996). However, the impacts will vary from place to place depending on

*E-mail: r.nicholls@mdx.ac.uk local and regional biogeophysical and socioeconomic factors.

This paper examines the regional implications of accelerated sea-level rise: a scale which is attracting increasing interest for all aspects of climate change due to the demands of policy makers (Watson et al. 1998). Such a regional perspective could be of benefit for both assessing the need for mitigation to reduce greenhouse gas emissions and/or improving the potential for adaptation to climate change. Three main benefits of a regional perspective are apparent. Firstly, if critical impacts are shared between neighbouring countries, calls for mitigation can be articulated more effectively by a group of nations to the wider international community. A regional-scale problem is more likely to encourage a significant mitigative response. Secondly, common impacts shared between countries provides opportunities to pool resources, share experience and integrate research efforts towards developing effective adaptive solutions. Lastly, a regional perspective is important irrespective of adaptation/ 


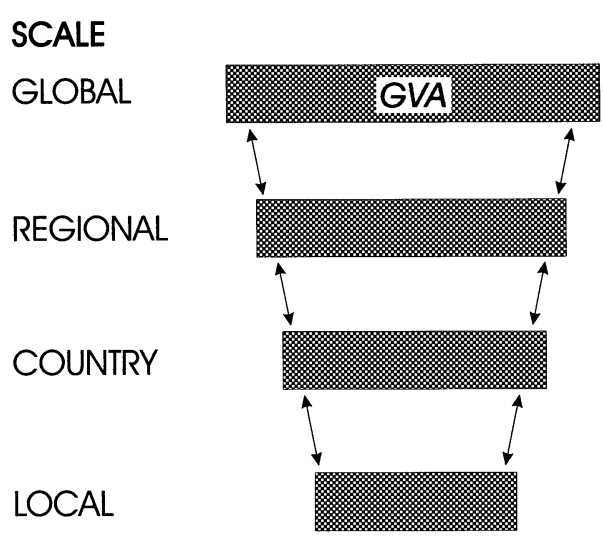

Fig. 1. Relationship of the different scales of vulnerability assessment. GVA: global vulnerability analysis

mitigation to anticipate a range of potential crossborder issues, such as physical changes (e.g. interruption of sediment supply) or socioeconomic changes (e.g. the creation of environmental migrants and refugees). All these issues are pertinent to the impacts of climate change on coastal zones.

An immediate problem is the precise definition of a region. Hoozemans et al. (1993) defined 20 contiguous coastal regions, while Watson et al. (1998) defined 10 regions, although small island states are considered as 1 region, so a region is not necessarily geographically contiguous. These 2 differing sets of definitions show that the concept of a region is a little fuzzy. For the purposes of this paper, a region is simply taken as a geographically continuous area containing more than 1 nation state. The 4 regions considered here all comprise at least 10 countries, but, taking the example of Canada and the USA, just 2 countries comprise the region of N orth America (cf. Watson et al. 1998). This illustrates that for large countries, such as the USA, Brazil, Russia or Australia, the distinction between national and regional analyses will tend to be less than for smaller countries.

The extent to which homogenous patterns of vulnerability to sea-level rise might emerge within regions will depend on the degree of homogeneity in the range of biogeophysical and socioeconomic factors which influence this vulnerability. Even if these parameters are quite heterogenous, then regional vulnerability might still be an issue to be addressed due to crossborder exchange as already outlined. An increasing number of sub-national and national studies are becoming available (e.g. Nicholls 1995b), providing the basis for aggregated or 'bottom-up' perspectives on regional vulnerability. In addition, a global assessment of impacts of sea-level rise also provides a regional perspective (Hoozemans et al. 1993). Using some of these studies, combined with broader analysis, we will consider the utility of a regional perspective on coastal vulnerability, and identify issues which are usefully addressed at this scale versus those which are better handled at national or global levels. Fig. 1 defines the different scales and their relationship. The regional scale provides an important link between the national and global scales.

\section{GLOBAL CLIMATE CHANGE AND ITS COASTAL IMPLICATIONS}

Global sea levels rose 10 to $25 \mathrm{~cm}$ over the last century and are expected to rise about $0.5 \mathrm{~m}$ by 2100 , equivalent to a 2 - to 5 -fold acceleration (Warrick et al. 1996). There is a wide uncertainty and the probabilistic analysis of Titus \& Narayanan (1996) estimated the 5 and 95 percentiles in 2100 to be a 5 and a $77 \mathrm{~cm}$ rise in sea level, respectively, with a $1 \%$ chance of the rise exceeding $1 \mathrm{~m}$. (In addition, existing studies only estimate the portion of global sea-level rise caused by anthropogenic climate change, excluding other factors such as natural variability, groundwater depletion and ocean basin changes. Existing models underpredict historic sea-level rise [1880 to 1980] by about $1 \mathrm{~mm} \mathrm{yr}^{-1}$ [Titus \& Narayanan 1996, Warrick et al. 1996], so this discrepancy adds about $10 \mathrm{~cm}$ of uncertainty to future projections.) These analyses are based on the IPCC IS92a greenhouse gas emissions scenario, which assumes 'business-as-usual' (Wigley \& Raper 1992, Warrick et al. 1996). Mitigation policies would slow, but not stop, the expected rise even given stabilisation of greenhouse forcing in the next few decades (which seems an optimistic goal). This has been termed the 'commitment to sea-level rise' (Warrick \& Oerlemans 1990, Wigley 1995) and it suggests that some adaptation to sea-level rise will be essential during the next century.

Sea-level rise also has a local and regional distribution because of the regional oceanographic responses to global warming and the local/regional uplift or subsidence of the land surface; the sum of these 3 components is termed relative sea-level change (Klein \& Nicholls 1998a). Presently, relative sea-level rise scenarios are difficult to develop due to our incomplete knowledge of the local and regional components. All the above uncertainties must be considered when interpreting impact and response assessments.

The most serious physical impacts of sea-level rise are: (1) inundation and displacement of wetlands and lowlands; (2) coastal erosion; (3) increased coastal storm flooding; and (4) salinisation (Barth \& Titus 1984). The impacts would vary from place to place and depend on the magnitude of relative sea-level rise, 
coastal morphology/topography and human modifications. The most threatened areas are deltas, low-lying coastal plains, coral islands, beaches, barrier islands, coastal wetlands, and estuaries (Tsyban et al. 1990, Bijlsma et al. 1996). It is important to note that sea-level rise interacts with other natural factors. For instance, a sediment supply could counter erosion due to sea-level rise, and vice versa.

M any other climate change factors could also have significant coastal implications at the regional scale. Given the large loss of life and destruction associated with tropical cyclones, changes in their strength and track raise strong concern (e.g. McLean \& Mimura 1993). However, with a few exceptions, the future changes to these climate factors are less certain, with a possibility of both increase or decrease. For the purposes of this paper, other climate factors are not considered further, although it is our expectation that they would raise similar issues.

\section{IM PACT ASSESSMENT FOR SEA-LEVEL RISE}

The IPCC Common Methodology (CM) was developed to improve understanding of societal vulnerability to sea-level rise (IPCC CZMS 1992). The CM and similar approaches have been applied in more than 24 national assessments and 1 global assessment (Nicholls 1995b) and the ongoing U.S., Dutch and other country studies programmes (e.g. Leatherman \& Yohe 1996). It stimulated a major debate on methods to assess climate change impacts in coastal areas (e.g. McLean \& Mimura 1993, Bijlsma et al. 1996). As a result, alternative approaches to vulnerability assessment were developed, most particularly for small South Pacific islands (Yamada et al. 1995). In addition, the generic IPCC technical guidelines for assessing climate change impacts and adaptations have been developed (Carter et al. 1994, Parry \& Carter 1998) and then transformed into a form appropriate for coastal regions (Klein \& Nicholls 1998a, b).

Collectively, this experience shows that there are still barriers to the conduct of comprehensive impact and response analyses due to: (1) incomplete knowledge of the relevant processes affected by sea-level rise and their interactions; (2) insufficient data on existing conditions; (3) difficulty in developing the local and regional scenarios of future change; and (4) the lack of appropriate analytical methodologies for some impacts.

While some studies have looked at sea-level rise scenarios in the range $10 \mathrm{~cm}$ to as much as $2 \mathrm{~m}$, most existing studies have focussed on a $1 \mathrm{~m}$ rise in global sea level on the present (1990s) situation applied directly as a relative sea-level rise scenario. In general, only the direct effects of sea-level rise such as inundation and erosion were considered and dynamic processes such as wetland response were ignored. Therefore, these results tend to overstress the effects of sea-level rise and understate the effect of other changes such as population growth and migration to the coast. However, if interpreted with the relevant assumptions in mind, these studies provide important insights into the potential impacts of sea-level rise.

\section{REGIONAL IM PACTS OF SEA-LEVEL RISE}

First, a global review of national studies is discussed in terms of regional implications (see Nicholls 1995b for a more detailed discussion). Then the relative vulnerability of 20 coastal regions is discussed, based on Hoozemans et al. (1993). Lastly, a more detailed analysis and synthesis of 4 contrasting regions is undertaken using local and national studies. The selected regions do not necessarily coincide with those defined by Hoozemans et al. (1993) and are (1) Europe, (2) West Africa, (3) South, South-East and East Asia and (4) the Pacific Small Islands.

\section{1. $N$ ational assessments: susceptible coastal areas}

Nineteen national vulnerability assessment studies are compared in a relative sense in Fig. 2 using a vulnerability profile (cf. IPCC CZMS 1992). Table 1 gives the class definitions, which should be interpreted in a relative rather than an absolute sense. The results show considerable variation in the degree of impacts from country to country, reflecting that certain settings are more vulnerable than others. This conclusion is widely supported by all the available studies (Bijlsma et al. 1996). Small islands, deltaic settings and coastal ecosystems appear particularly vulnerable.

All deltas are low lying and many are densely populated. They naturally subside and hence experience a relative rise in sea level without any global rise. In general, human activity is reducing the sediment supply that has created and then sustained the subsiding delta surface. Sub-surface fluid withdrawals enhance rates of subsidence. Based on present conditions, options to respond to sea-level rise are limited, and many populated deltas appear highly vulnerable to sea-level rise. Given the large concentration of populated deltas in South, South-East and East Asia, the impacts of sealevel rise on deltas has a regional dimension (Nicholls et al. 1995).

Small islands are generally vulnerable to sea-level rise due to their low resource base and hence high susceptibility to climate and other changes (Pernetta 1992). 


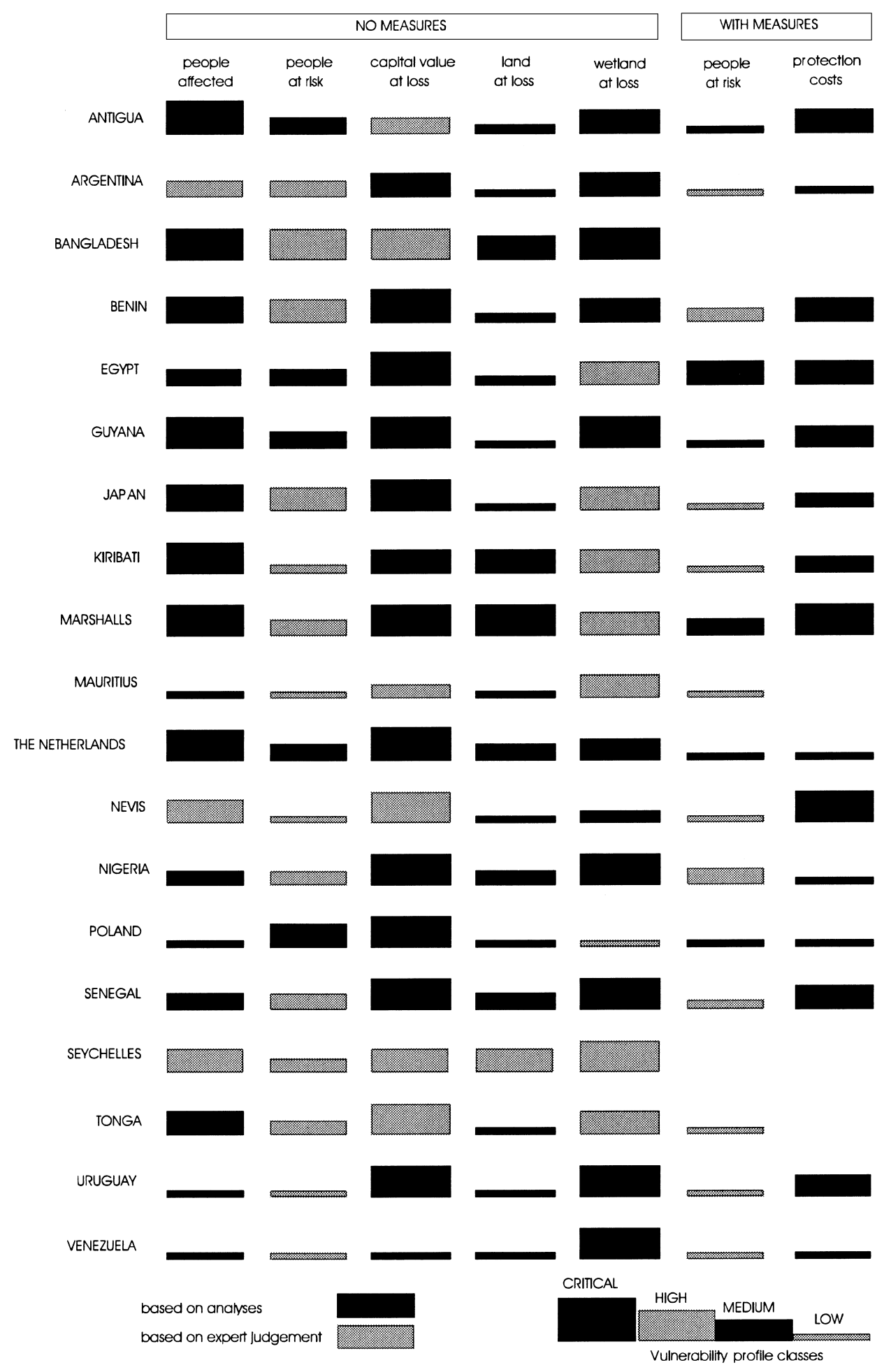

Fig. 2. Vulnerability profiles for national assessments (from Nicholls 1995b)

This is most apparent on low-lying coral atolls, where the highest point is only a few metres above sea level and all the impacts of sea-level rise could have serious consequences. Increasing human pressures, the lack of resources, and the limited size of the islands severely limit adaptation options, and these areas must be considered highly vulnerable to sea-level rise (Bijlsma et al. 1996). While less critical, non-atoll islands, such as 
Table 1. Vulnerability classes used in Fig. 2. Annual protection/adaptation costs are calculated assuming total costs are incurred uniformly over 100 yr (taken from IPCC CZMS 1992). GNP: gross national product

\begin{tabular}{|c|c|c|c|c|}
\hline \multirow[t]{2}{*}{ Impact categories } & \multicolumn{4}{|c|}{ Vulnerability classes } \\
\hline & Low & Medium & High & Critical \\
\hline People affected (no. of people/total population) $\times 100 \%$ & $<1 \%$ & $1-10 \%$ & $10-50 \%$ & $>50 \%$ \\
\hline People at risk $\Sigma$ (no. of people $\times$ flood probability) / 1000 & $<10$ & $10-100$ & $100-500$ & $>500$ \\
\hline Capital value loss (total loss/1990 GNP) $\times 100 \%$ & $<1 \%$ & $1-3 \%$ & $3-10 \%$ & $>10 \%$ \\
\hline Land loss (area loss/total area) $\times 100 \%$ & $<3 \%$ & $3-10 \%$ & $10-30 \%$ & $>30 \%$ \\
\hline Protection/adaption costs (annual cost/1990 GNP) $\times 100 \%$ & $<0.05 \%$ & $0.05-0.25 \%$ & $0.25-1 \%$ & $>1 \%$ \\
\hline Wetland loss (area loss/total area) $\times 100 \%$ & $<3 \%$ & $3-10 \%$ & $10-30 \%$ & $>30 \%$ \\
\hline
\end{tabular}

those in the Pacific (Nunn \& Mimura 1997) and also in other areas such as the Mediterranean (Nicholls \& Hoozemans 1996), will also face serious problems given sea-level rise. Therefore, as with deltas, the vulnerability of small islands has regional implications.

Coastal wetlands and tidal flat areas appear to be threatened with loss or significant change in most locations as their present location is intimately linked with the present sea level. Sedimentation and/or organic matter input can maintain the surface elevation relative to a rising sea level, but this process was largely ignored in many assessments (Nicholls 1995b). Wetlands in microtidal areas and/or oceanic settings have the lowest inputs of sediment and organic matter and hence are considered most vulnerable to inundation (Stevenson et al. 1986, Snedaker et al. 1994). In addition, inland migration of wetlands onto adjacent lowlying dryland areas may replace wetlands that are lost as sea level rises; however, a net loss will occur in most areas because the current area of wetlands is generally much greater than the amount of dry land within $1 \mathrm{~m}$ above high water (e.g. Titus et al. 1991). Flood and coastal erosion protection structures cause coastal squeeze and remove the possibility of wetland migration (Bijlsma et al. 1996, Titus 1998). Lastly, wetlands are declining globally at about $1 \% \mathrm{yr}^{-1}$, largely due to direct human reclamation (Hoozemans et al. 1993). Therefore, vulnerable wetlands may be lost before being adversely impacted by sea-level rise. While the problems of coastal wetlands appear fairly universal, they have regional dimensions, e.g. the temperate saltmarshes of mid and high latitudes versus the tropical mangroves of lower latitudes. Sharing scientific data and management experience concerning wetlands within a region would improve vulnerability assessments and long-term wetland management.

\subsection{Regional and global analyses}

The CM was applied at a global scale in the 'global vulnerability analysis' (or GVA) with the objective of obtaining regional and global results (Hoozemans et al. 1993). Using scenarios of the 1990 and 2020 socioeconomic situation, the following factors were evaluated: (1) flooding due to storm surge, (2) potential protection costs against flooding and (3) wetland loss. The GVA is a first-order analysis performed using somewhat limited global data sets and a number of assumptions. Calculations were performed at the national scale and results were aggregated to the regional and global scale. Subsidence was considered, aiding identification of regional effects.

Globally, it is estimated that up to 50 million people are flooded by storm surge each year (Hoozemans et al. 1993). M ost of these people live in deltaic areas in the developing world, which is consistent with the national assessments above. Considering increases relative to the 1990 situation, the expansion of the flood plain due to a $1 \mathrm{~m}$ sea-level rise will increase the number of people flooded to 60 and 100 million people based on 1990 and 2020 populations, respectively. Allowing for the additional factor of increased flood frequency within the existing coastal flood plain 120 million people would be flooded, just based on the 1990 population (Baarse 1995). Such flooding can be prevented by building or raising existing dikes. To be effective, the height of a dike needs to consider both sea-level rise and the storm surge. Following this approach, (1) flood defence of low-lying coasts, (2) maintaining tourist beaches using nourishment, and (3) port and harbour upgrade against a $1 \mathrm{~m}$ rise in sea level could collectively cost US $\$ 1000$ billion (1990 dollars), or $5.6 \%$ of the 1990 global world income. These cost estimates assume an instantaneous rather than a progressive response and do not consider erosion in non-tourist areas or the costs of improving water management and drainage. Therefore, they are most useful as a relative rather than an absolute cost. Coastal wetlands would decline significantly due to a $1 \mathrm{~m}$ rise in sea level: more than half of the world's coastal wetlands could be lost (Hoozemans et al. 1993), again agreeing with the national assessments. 


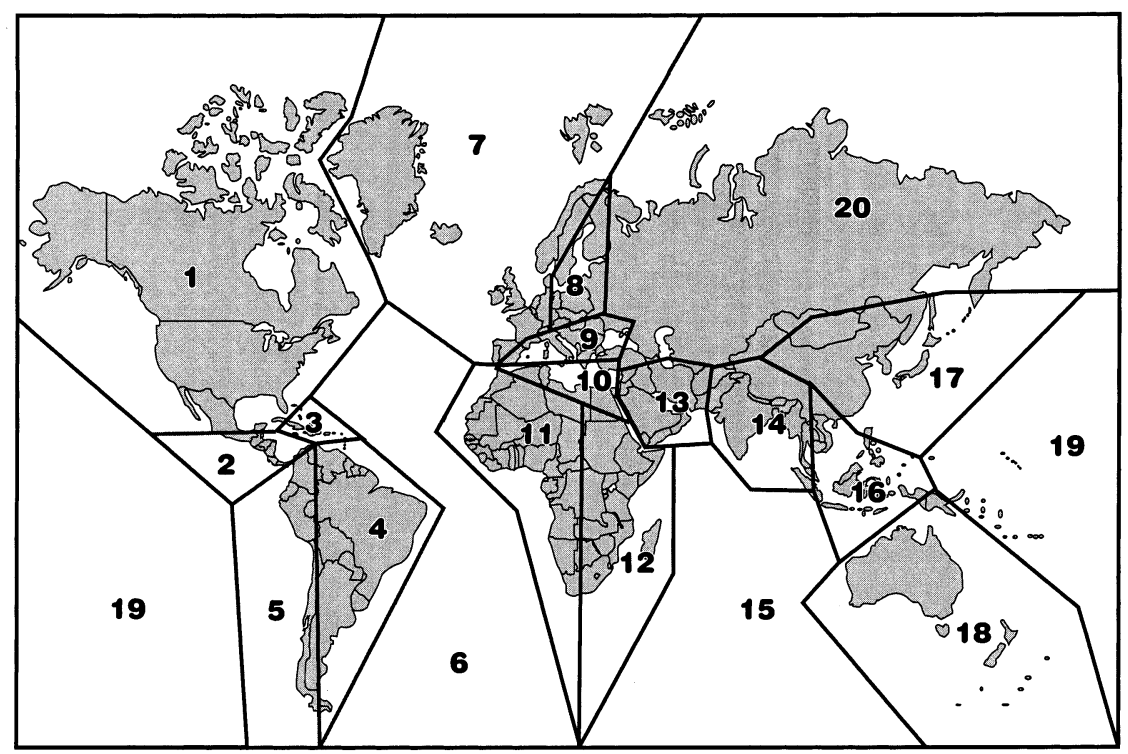

Fig. 3. The 20 regions used in the GVA (taken from Hoozemans et al. 1993)

Considering the relative vulnerability to sea-level rise of the 20 coastal regions shown in Fig. 3 (Hoozemans et al. 1993), 6 regions are vulnerable to the loss of coastal wetlands: North America; Central America; South America Atlantic Coast; N orth and West Europe; Northern Mediterranean; and Pacific Large Islands (GVA regions 1, 2, 4, 7, 9 and 18). Nine regions were considered to be vulnerable with respect to both flood impacts/response costs and loss of coastal wetlands: Caribbean islands; Southern Mediterranean; West A frica; East A frica; South Asia; the Indian Ocean small islands; South-East Asia; East Asia; and Pacific Small Islands (GVA regions 3, 11, 15, 17, 19, 10, 14, 16 and 12). Relative flood impacts are significant for small island settings, but the absolute impacts are highest in South, South-East and East Asia.

To further explore regional vulnerability to sea-level rise, 4 contrasting regions are investigated in more detail using local and national assessments: (1) Europe, excluding the former Soviet Union (GVA regions 7, 8 and 9), which is an industrialised region; (2) West Africa (GVA region 11), where high coastal population growth is expected; (3) South, South-East and East Asia (GVA region 14, 16 and 17), which contains a large number of densely populated deltas, and (4) the Pacific Small Islands (GVA region 19). Due to the nearuniversal vulnerability of coastal wetlands to sea-level rise, this is only considered if there is a specific regional dimension to the problem.

\subsection{Regional assessment: Europe}

In Europe, important population and economic centres are concentrated in the coastal zone. Some coastal areas, such as much of The Netherlands, the fens in eastern England and the Po River Plain (Italy), are already beneath mean sea level, while many more areas are vulnerable to flooding from storm surges. Fixed rigid defences to prevent such flooding, combined with present sea-level rise, are al ready causing a significant coastal squeeze: a decline in intertidal coastal habitats (e.g. Pethick 1993). The available national results all emphasise the large potential human and ecological impacts of sea-level rise (Table 2). Local studies, such as East Anglia, United Kingdom (Turner et al. 1995), and Rochefort sur Mer, France (Auger 1994), as well as regional reviews (Tooley \& J elgersma 1992, Nicholls \& Hoozemans 1996) support this conclusion. In terms of adaptation costs, Poland appears more vulnerable than Germany and The N etherlands (Table 2).

Because most low-lying coastal areas in Europe are already protected from flooding, a small rise in sea level will not cause serious inundation of human-occupied areas. Assuming other climatic factors remain constant, the protection offered by the flood defence will decline as sea level rises (Kelly 1991). Fankhauser (1995) assessed the costs of protection (including the monetary values of nature) versus the costs of land loss for the OECD (Organisation for Economic Cooperation and Development) and, hence, provides an analysis of responses pertinent to Europe. He concludes that it is optimal to protect nearly all harbours and cities and open coasts and beaches in densely populated areas (e.g. The Netherlands) and in areas where beach tourism is important (e.g. Greece and Spain). In areas with low population density (e.g. Norway and Iceland) and lower income (e.g. Turkey) a lower level of protection is optimal. The scale of assessment is also a key 
issue. Turner et al. (1995) analysed protection in East Anglia, England. At the aggregated scale of East Anglia, protection can be justified for the entire coast. However, when the individual flood compartments are evaluated, $20 \%$ would optimally be abandoned even for scenarios of relative sea-level rise $(10 \mathrm{~cm}$ rise in sea level by 2050) similar to present rates.

In some European countries, coastal infrastructure has been planned for sea-level rise for many decades (e.g. Kelly 1991) and now similar adaptation which anticipates accelerated sea-level rise is also being implemented (e.g. UK Department of Environment 1996). However, maintaining and raising existing lines of flood defences does nothing to stop coastal squeeze. In Britain, to counter coastal squeeze in estuaries, managed retreat (often termed managed realignment) is being considered, particularly in areas where lowlying, low value agricultural land exists landward of the flood defence (Burd 1995). About 100 ha of land would need to be released per year just to counter present rates of saltmarsh loss due to sea-level rise. While the economic analysis of Turner et al. (1995) would suggest that there are many suitable sites available, this requires strategic planning, which is being put in place as part of shoreline management planning (UK Ministry of Agriculture, Fisheries and Food et al. 1995, Leafe et al. 1998). Nonetheless, it remains unclear if managed retreat at the scale necessary to sustain the existing stock of saltmarsh will be both technically and politically acceptable in Britain. The Netherlands is highly threatened by sea-level rise (Table 2), with about $60 \%$ of the country $\left(23600 \mathrm{~km}^{2}\right)$ and 10 million people being in the impact zone (Baarse et al. 1994). A new national law outlaws erosion and mandates maintenance of the present shoreline position (Koster \& Hillen 1995). However, other opinions are emerging which favour a managed retreat and allowing coastal dynamics to occur in a controlled manner (Helmer et al. 1996, Klein et al. 1998). These ideas represent a radical departure from Dutch traditions and it will be interesting to evaluate which policies prevail. In general, sea-level rise is raising concern about coastal squeeze in many European countries.

Across Europe, a more strategic and integrated perspective to coastal management is being developed, which includes adaptation to climate change. The European Union (EU) is presently promoting demonstration projects in Integrated Coastal Zone M anagement (ICZM) across the member states. One pertinent issue is cross-border transport of sediment, which reduces the vulnerability of the receiving country to sea-level rise. For instance, coastal erosion of Holderness in eastern England helps to sustain saltmarshes in the Wadden Sea in The Netherlands and Germany (Eisma 1981, Dyer \& M offat 1998), and presumably the

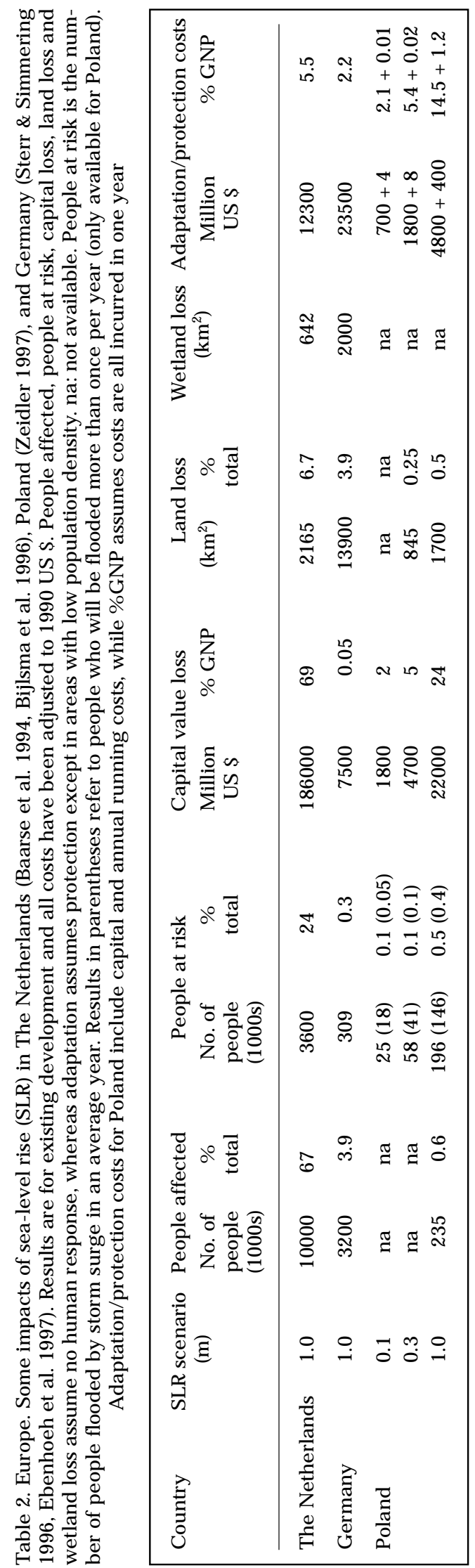


Dutch and Germans would like this erosion to continue. This provides an additional need for a regional perspective on the coastal impacts of sea-level rise.

In conclusion, Europe's vulnerability to sea-level rise is relatively low due to its wealth, its historic investment in coastal and flood protection, and its active evaluation of coastal management approaches, including anticipation of sea-level rise. A common problem across Europe is developing strategic management approaches which both allow continued human utilisation of the coastal zone and preserve coastal ecosystems given sea-level rise. The slow but steady degradation of the coastal fringe in much of Europe has gone largely unnoticed until recently, and this will continue and accelerate with sea-level rise. Responding to coastal squeeze is a complex question embracing the natural, engineering and social sciences, together with public policy. Exchange of research and experience will be beneficial, particularly if regions are based on similar tidal characteristics: (1) the Mediterranean, (2) the Baltic, and (3) the North Sea/Atlantic. The existence of the EU promotes such regional cooperation.

\subsection{Regional assessment: West Africa}

Unlike Europe, the West African coast is relatively undeveloped and there is limited coastal engineering, except at harbours (Ibe 1990). However, existing coastal hazards are already a worry and the coastal population is growing rapidly (Hoozemans et al. 1993). When combined with the low-lying nature of the coast and the low level of socioeconomic and institutional development, these factors would suggest that West Africa is vulnerable to sea-level rise. Three recent studies of Senegal (Dennis et al. 1995), Benin (Adam 1995) and Nigeria (French et al. 1995) provide some information on potential impacts on the 1990 situation given a $1 \mathrm{~m}$ rise in sea level (Table 3 ).

Large areas of land could be lost in all these countries. Most of the threatened land is wetland areas within deltas, or around estuaries and lagoons. The problem of land loss in the Niger delta will be compounded by local subsidence and sediment starvation.
M oreover, important resources to human society could also be affected. In Senegal, most tourist facilities could be destroyed and up to 180000 people could lose their homes. In Benin, the coastal zone is densely populated and 1.35 million people (or $25 \%$ of the population) could lose their homes and economically important infrastructure would be lost or damaged. In Nigeria, it is estimated that 3.2 million people could be displaced from their homes. Over 2 million of these people live in Greater Lagos and other urban areas. In addition to urban infrastructure in and around Lagos, the Niger delta is also economically highly at risk mainly due to infrastructure related to the oil industry.

The above numbers assume no response to sea-level rise. In Senegal, protection removes most of the direct human impacts. In Nigeria, most people might be protected, but 600000 people living in the Niger delta might require relocation as conventional protection with sea walls would be impossible without a very large investment and the application of new technology. Significant land loss would still be expected to occur as many areas would not require protection based on present human use of the coastal zone. In Benin, protection is feasible, but the costs in Table 3 are likely to be low estimates.

This represents assessments of a $1 \mathrm{~m}$ rise in sea level for the 1990s' socioeconomic situation. If the rapid population growth in the region is considered, the impacts could be more significant. The 7 coastal cities with more than 1 million people in 1990 (from Rabat, M orocco, to Luanda, Angola) had a collective population of 21 million people. This will increase to a projected population of 51 million people by 2010 (UN Population Division 1993). The most dramatic change is Lagos growing from 8 million people to 21 million people and gaining the status of one of the world's 10 largest cities. Such rapid increases suggest that vulnerability to sea-level rise will increase substantially over the next few decades, unless these changes are carefully planned.

In conclusion, West Africa appears to be vulnerable to accelerated sea-level rise, but there are insufficient national or regional studies to reach more precise conclusions. A regional theme is the existing concentra-

Table 3. West Africa. Summary impacts and response costs for a $1 \mathrm{~m}$ sea-level rise for Senegal, Nigeria, and Benin (after Bijlsma et al. 1996). Definitions and prices as in Table 2

\begin{tabular}{|c|c|c|c|c|c|c|c|c|}
\hline \multirow[t]{2}{*}{ Country } & \multicolumn{2}{|c|}{ Land loss } & \multicolumn{2}{|c|}{ Population affected } & \multicolumn{2}{|c|}{ Capital value loss } & \multicolumn{2}{|c|}{ Adaptation/protection costs } \\
\hline & $\mathrm{km}^{2}$ & $\%$ & $1000 \mathrm{~s}$ & $\%$ & Million US \$ & $\%$ GNP & Million US \$ & $\%$ GNP \\
\hline Senegal & 6000 & 3.1 & $>110$ & $>1$ & $>500$ & $>12$ & $>1000$ & $>21$ \\
\hline Nigeria & 18000 & 2.0 & 3200 & 4 & 17000 & 52 & $>1400$ & $>4$ \\
\hline Benin & 230 & 0.2 & 1350 & 25 & 118 & 12 & $>400$ & $>41$ \\
\hline
\end{tabular}


tion of human activity at the coast combined with rapid population growth and a need for coastal development. Therefore, planned relocation of development inland out of the coastal zone can only be a partial solution. As a first step, more detailed vulnerability assessment, including analysis of the possible role of socioeconomic changes, should be given a high priority in all 20 countries in West Africa. In addition, all new development should include planning for coastal hazards, including sea-level rise, although given the rapid rate of development and the immediate needs of the local population this is difficult to achieve (Ibe 1990, Nicholls et al. 1993). A regional exchange of these results and experience would have important benefits. Potential regional research projects could include common issues such as the response of mangroves to sea-level rise (cf. Holligan \& de Boois 1993). Longshore exchange of sand across national boundaries, such as from G hana towards Nigeria, is also of regional interest (Nicholls et al. 1993).

\subsection{Regional assessment: South, South-E ast and East Asia}

In contrast to West Africa, this region has been more extensively studied, particularly the consequences of sea-level rise for the low-lying deltaic plain of the Ganges-Brahmaputra in Bangladesh (e.g. Milliman et al. 1989, Warrick \& A hmad 1996). The other coastal countries in the region all have populated deltas which are vulnerable to sea-level rise, particularly India, Vietnam, China and Thailand. Tropical cyclones are often a problem, particularly in Bangladesh and India. If the intensity and patterns of tropical cyclones and monsoons change, the whole region will be affected significantly, though such changes are still highly uncertain. Like West A frica, coastal urbanisation is an issue: 13 coastal megacities (population $>8$ million) are forecast in this region by 2010 (Nicholls 1995a, Nicholls et al. 1995). In many of these cities, groundwater withdrawals have enhanced subsidence, causing a large relative rise in sea level. Tokyo, Osaka and Shanghai formerly experienced rapid subsidence of up to $5 \mathrm{~m}$ and now depend on dikes for flood protection, while J akarta, Bangkok and Tianjin were actively subsiding at maximum rates on the order of $5 \mathrm{~cm} \mathrm{yr}^{-1}$ during the past decade (Nicholls 1995a). It seems likely that similar problems will emerge in other 'new' and expanding coastal cities in the region, such as Hanoi (see Toms et al. 1996).
Assuming no adaptation, estimated land loss due to sea-level rise and the present population of these areas are given in Table 4. Most of the threatened land is in deltaic settings and these impacts could be exacerbated by subsidence and human modifications to the deltaic sediment budget. Results are most dramatic in Bangladesh and Vietnam, where 15 million and 17 million people, respectively, could be displaced. In China, a $1 \mathrm{~m}$ rise in sea level would increase the $100 \mathrm{yr}$ flood plain to $125000 \mathrm{~km}^{2}$, an area with a rapidly growing population of 72 million (1987 data) (Han et al. 1995). Based on present trends, significant growth of all these susceptible populations would be expected. In Japan, $2300 \mathrm{~km}^{2}$ would be beneath high water given a $1 \mathrm{~m}$ rise in sea level: an area with a present population of over 4 million (Mimura et al. 1994). However, these areas are already protected by high dikes which are likely to be raised and the problem is one of changing flood risk rather than population displacement.

Agriculture presently plays a major role in the economies of the region (Nicholls et al. 1995). About $10 \%$ of the regional rice production (or enough rice to feed 200 million people) is located in areas which are susceptible to a $1 \mathrm{~m}$ rise in sea level (Hoozemans et al. 1993). Direct loss of land combined with less favourable hydraulic conditions may reduce rice production yields by $4 \%$ if no adaptation measures are taken, endangering the food supply of 75 million people (Hoozemans et al. 1993). Saltwater intrusion and soil salinisation are other concerns for agricultural productivity. Based on national studies, a $1 \mathrm{~m}$ rise could cause losses of about 9.5 million $t$ of rice in Bangladesh and $16000 \mathrm{~km}^{2}$ of rice paddy in Indonesia (Nicholls et al. 1995), while, in Vietnam, $25000 \mathrm{~km}^{2}$ of rice paddy (or about half the national area) would be subject to annual flooding (Toms et al. 1996). Collectively, these results suggest that Hoozemans et al. (1993) may have underestimated the regional impact of sea-level rise on rice production. 
As sea level rises, so major coastal cities will need to be protected - the subsiding cities, such as Bangkok and J akarta, will probably required improved protection and water management without any global sealevel rise. Allowance for sea-level rise, including subsidence, has been made for recent reclamations in Hong Kong (Yim 1995). However, in other settings such as deltas, insufficient scientific information is available to make long-term management decisions.

In conclusion, the fact that the region is vulnerable to sea-level rise and climate change is recognised and the subject of ongoing investigation. A range of interrelated and shared problems are apparent given sealevel rise, such as delta management, mangrove management, impacts on coastal agriculture and subsiding cities. Regional coordination of research efforts and exchange of management experience could be beneficial to all the nations participating.

\subsection{Regional assessment: Pacific Small Islands}

In the Pacific there have been a number of studies, including the relatively high islands of Tonga (Fifita et al. 1994), Fiji (Nunn et al. 1996) and Western Samoa (Nunn et al. 1994), and the low-lying atoll islands of Tuvalu (Sem et al. 1996). All these islands are found to be vulnerable to sea-level rise. Tuvalu is low-lying with a mean elevation of $1.5 \mathrm{~m}$ above mean sea level. Any rise in sea level increases the frequency of flooding: about two-thirds of the sites considered would be inundated by a $1 \mathrm{~m}$ rise in sea level, and this would be exacerbated by increased wave action. The other islands would also be affected by sea-level rise because the population is concentrated along the lowlying coastal plains at low elevations, even though these islands have relatively high interiors. The risk of inundation and flooding has been intensified by population migration from the outer islands to the capitals in each island country. Due to the traditional system of land ownership in the south Pacific, these migrants cannot buy or rent land and they often settle in the areas most likely to be affected by sea-level rise such as on low-elevation reclamations.

Beach erosion is already a problem and most coastal villages studied in Fiji have built seawalls since 1960 (Mimura \& Nunn 1998). A range of factors may be responsible, including sea-level rise, increased population density and human modifications to the coast such as clearing mangroves and damaging coral reefs. If these trends continue, local people would evacuate from the villages where they have historically lived, which in turn causes a loss of traditional culture and social instability. Accelerated sea-level rise and climate change could also affect modern infrastructure, including ports, harbours and coastal resorts. A high vulnerability to sea-level rise is a common feature of the region, and this is partly related to social and cultural traditions.

Response options to sea-level rise often focus on the technical options of (1) planned retreat, (2) accommodation, and (3) protection (IPCC CZMS 1990, Bijlsma et al. 1996). Vulnerability is produced by several factors, including a low resilience (or ability to bounce back after perturbations such as sea-level rise) (Klein \& Nicholls 1998b). Therefore, enhancing natural and human resilience is an effective adaptation to sea-level rise. Suggested measures can be divided into 3 categories: (1) information measures, including studies to predict future changes and their impacts; (2) technical measures, in terms of coastal planning and engineering (including the retreat, accommodate and protect options above); and (3) social and economic measures, which aim to increase the human resilience. While there is no single solution to the problem of sea-level rise, an appropriate combination of such measures can reduce the vulnerability of the coast to future threats. In atoll settings, response options are most limited and ultimate island abandonment remains a real possibility in the face of sea-level rise.

In conclusion, the Pacific Small Islands appear to be highly vulnerable to sea-level rise due to a range of physical, social and cultural factors. As with South, South-East and East Asia, there is an increasing understanding of this problem and response strategies are being considered, at least in a preliminary manner. For the Pacific Small Islands, regional cooperation in developing vulnerability assessment and response strategies is essential as the commonality of the problems is high, and many of the countries are too small to solve them alone.

\section{DISCUSSION}

This review shows that the nature of the problems produced by sea-level rise varies between and within regions due to a range of natural, socioeconomic, institutional and cultural factors. It is important to emphasise that there are no winners given sea-level rise, rather there are small losers and big losers. While Europe is less vulnerable than the other regions, the protection of people and the economy needs to be balanced against the costs of degradation of the coastal environment.

Table 5 summarises some of the important regional issues which the preceding analysis has raised. The regional issues are all associated with adaptation to climate change, although they would all benefit from a reduction in the magnitude of climate change (i.e. mit- 
igation). This is most obvious for the Pacific Small Islands, who have limited adaptation options, particularly the islands composed of coral atolls. Lobbying for mitigation is an effective long-term strategy in this case. This is already happening via the Alliance of Small Island States (AOSIS) which is championing the case of small islands to the world community. The membership of AOSIS comes largely from 3 vulnerable regions composed of small islands: the Caribbean, the Indian Ocean small islands and the Pacific Small Islands. Given the commitment to sea-level rise already discussed, and the uncertainty about the success of efforts at mitigation, regional research efforts to enhance resilience and increase adaptation options for small islands would also be prudent.

$M$ any of the regional responses suggested in Table 5 could be accomplished at the national level, but the commonality of the problems means that regional collaboration would be more efficient. However, 2 sets of problems could not be solved at the national level: small islands due to their limited resources and the management of cross-border sediment transfer. Deltaic management must be linked to catchment management, which raises similar problems if the river catchment crosses frontiers: Bangladesh is a wellknown example, but there are many others (Reibsame et al. 1995). Other problems which might emerge due to sea-level rise such as international environmental migrants and refugees are best handled at a regional scale and in an anticipatory manner. Therefore, in policy terms, we can distinguish between essential regional activities and recommended regional activities.

International efforts such as the International Geosphere-Biosphere Programme-Land-Ocean Interactions in the Coastal Zone (IGBP-LOICZ) (Pernetta \& Milliman 1995) may be a focus for the science aspects of such efforts. For vulnerability assessment and coastal zone management efforts, 2 regional projects offer a good model: (1) Pacific Islands Climate Change Assisting Programme (PICCAP), implemented by the South Pacific Environmental Programme (SPREP); and (2) Caribbean: Planning for Adaptation to Climate Change (CPACC), implemented by the Organisation of American States (World Bank 1997). They are designed to increase national and regional capacities and resources to adapt to the potential impacts of climate change in 10 and 13 countries in the South Pacific and Caribbean, respectively.

The debate on the stabilisation of greenhouse forcing also requires information on the impacts of different emission pathways, including the effects of sealevel rise. Much of this work may be conducted at a regional scale for the purposes of simplicity. The model of Hoozemans et al. (1993) offers an appropriate tool

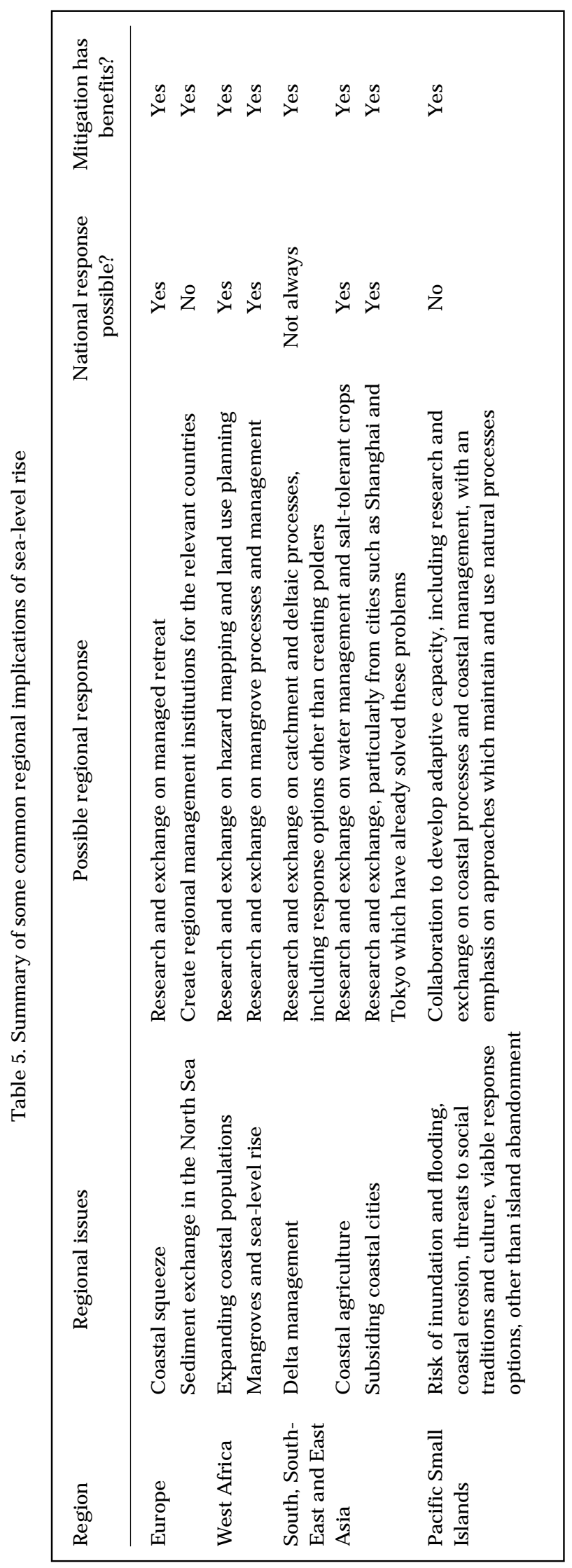


for this purpose, and has the potential to be integrated with other models. Such models require validation using national-scale results (Fig. 1).

A number of activities would be useful to improve our understanding of local, national and regional vulnerability to sea-level rise. In particular, there is a need for more assessment of the impacts of sea-level rise, including: (1) better integration of the natural and social sciences so that the relative role of climate change to non-climate-change factors can be more fully considered; and (2) more realistic evaluation of the range of possible response strategies (Strzepek \& Smith 1995, Bijlsma et al. 1996). The new guidelines by Klein \& Nicholls (1998a) may be helpful. These national studies will be useful for validating regional impact models such as Hoozemans et al. (1993). Improvement of data collection and management is another necessity to improve future vulnerability and adaptation assessments. Better coordination of future national studies to maximise their regional benefits should be considered.

In terms of adaptation, the appearance of the more apparent adverse impacts of sea-level rise on coastal areas is some decades away, and their actual magnitude has a high uncertainty. Therefore, only 'noregret' and low-cost anticipatory responses and 'insurance' responses in situations where sea-level rise would have large costs will be appropriate in the next few decades (Nicholls \& Leatherman 1996). Prevention of present beach erosion and enhancement of wetlands and mangroves are examples of the 'no-regret' options. Land use planning to control the over-concentration of the population in the susceptible low-lying areas are beneficial for avoiding the present day and future risks. The nature of these responses will vary from region to region. Sea-level rise and climate change will not occur in a vacuum and these responses need to be placed within an ICZM framework (Bijlsma et al. 1996, Cicin-Sain et al. 1997). Regional exchange will facilitate ICZM development and hence increase the capacity to adapt to climate change.

\section{CONCLUSIONS}

The key issues raised by future sea-level rise show significant variation by region from an increased flood risk and coastal squeeze in Europe to the possibility of island abandonment in some cases in the Pacific. It is important that this variation is considered when analysing possible responses to the human-enhanced greenhouse effect. Given that there are some commonalities within regions, regional coordinated efforts to assess vulnerability, the full range of responses and their application within an ICZM context will often be worthwhile. The precise boundary between what is appropriate at the national and regional level may be fuzzy, but in many cases, regional efforts will be more efficient in terms of developing and assessing adaptation options. For the small island nations, cooperation at the regional level appears essential if they are to develop a range of adaptation strategies and encourage efforts to mitigate climate change. Potential crossborder problems also demand some international (and hence regional) effort. Assessment of mitigation policies is likely to use regionally based models such as Hoozemans et al. (1993). These regional models require further national assessments for validation purposes. In conclusion, a regional perspective provides a useful link between research and policy at the national and global scales.

Acknowledgements. The authors acknowledge the reviews of $\mathrm{J}$ im Titus and 1 anonymous reviewer that greatly improved an earlier version of this paper.

\section{LITERATURE CITED}

Adam KS (1995) Vulnerability assessment and coastal management program in the Benin coastal zone. In: Beukenkamp P (ed) Proceedings of WCC'93. CZM Management Publication No. 4, National Institute for Coastal and $M$ arine $M$ anagement, The Hague, p 489-501

Auger C (1994) The impacts of sea-level rise on Rochefort sur Mer, France. In: O'Callahan J (ed) Global climate change and the rising challenge of the sea. Proceedings of the 3rd IPCC CZMS Workshop, Margarita Island, March 1992. NOAA, Silver Spring, MD, p 317-328

Baarse G (1995) Development of an operational tool for global vulnerability assessment (GVA): update of the number of people at risk due to sea-level rise and increased flood probabilities. CZM-Centre Publication No. 3, Ministry of Transport, Public Works and Water Management, The Hague

Baarse G, Peerbolte EB, Bijlsma L (1994) Assessment of the vulnerability of the Netherlands to sea-level rise. In: O'Callahan J (ed) Global climate change and the rising challenge of the sea. Proceedings of the 3rd IPCC CZMS Workshop, Margarita Island, March 1992. NOAA, Silver Spring, MD, p 211-236

Barth M C, Titus J G (eds) (1984) Greenhouse effect and sealevel rise. Van Nostrand Reinhold, New York

Bijlsma L, Ehler CN, Klein RJT, Kulshrestha SM, McLean RF, Mimura N, Nicholls RJ , Nurse LA, Perez Nieto H, Stakhiv EZ, Turner RK, Warrick RA (1996) Coastal zones and small islands. In: Watson RT, Zinyowera MC, Moss RH (eds) Impacts, adaptations and mitigation of climate change: scientific-technical analyses. Cambridge University Press, Cambridge, p 289-324

Burd F (1995) Managed retreat-a practical guide. English Nature, Peterborough

Carter TR, Parry ML, Nishioka S, Harasawa H (eds) (1994) Technical guidelines for assessing climate change impacts and adaptations. Report of Working Group II of the Intergovernmental Panel on Climate Change, University College London, London, and Centre for Global Environmental Research, Tsukuba 
Cicin-Sain B Ehler C, Knecht R, South R, Weiher R (1997) Guidelines for integrating coastal management programs and national climate change action plans. International Workshop: Planning for climate change through integrated coastal management, February 1997, Taipei. NOAA, Silver Spring, MD

Dennis K, Niang-Diop I, Nicholls RJ (1995) Sea-level rise and Senegal: potential impacts and consequences. J Coast Res Spec Iss No. 14:242-261

Dyer KR, M offat T (1998) Fluxes of suspended matter in the East Anglia Plume Southern N orth Sea. Cont Shelf Res (in press)

Ebenhoeh W, Sterr H, Simmering F (1997) Potentielle Gefaehrdung und Vulnerabilitaet der deutschen Nordund Ostseekueste bei fortschreitenden Klimawandel (case study based on the Common Methodology of the IPCC Subgroup B). Unpublished report

Eisma D (1981) Supply and deposition of suspended matter in the North Sea. In: Nio SD, Schuttenhelm RTE, Van Weering TCE (eds) Holocene marine sedimentation in the North Sea Basin. International Association of Sedimentologists, Spec Pub No. 5. Blackwell, Oxford, p 415-428

Fankhauser S (1995) Protection versus retreat: estimating the costs of sea-level rise. Environ Planning A 27:299-319

Fifita P, Mimura N, Hori N (1994) Assessment of the vulnerability to sea-level rise for the Kingdom of Tonga. In: O'Callahan J (ed) Global climate change and the rising challenge of the sea. Proceedings of the 3rd IPCC CZMS Workshop, Margarita Island, March 1992. NOAA, Silver Spring, MD, p 119-139

French GT, A wosika LF, Ibe CE (1995) Sea-level rise in Nigeria: potential impacts and consequences. J Coast Res Spec Iss 14:224-242

Han M, Hou J , Wu L (1995) Potential impacts of sea-level rise on China's coastal environment and cities: a national assessment. J Coast Res Spec Iss 14:79-95

Helmer W, Vellinga P, Litjens G, Goosen H, Ruijgrok E, Overmars W (1996) Growing with the sea-creating a resilient coastline. World Wide Fund for Nature, Zeist

Holligan P, de Boois H (eds) (1993) Land-ocean interactions in the coastal zone: science plan. IGBP Report No. 25, International Geosphere-Biosphere Programme, Stockholm

Hoozemans FMJ, Marchand M, Pennekamp HA (1993) A global vulnerability analysis, vulnerability assessments for population, coastal wetlands and rice production on a global scale, 2nd edn. Delft Hydraulics and Rijkswaterstaat, Delft

Ibe AC (1990) Adjustments to the impact of sea-level rise along the West and Central African coasts. In: Titus J G (ed) Changing climate and the coast, $\mathrm{Vol} 2$. Proceedings of the 1st IPCC CZMS Workshop, Miami, 27 November to 1 December 1989. Environmental Protection Agency, Washington, DC, p 3-12

IPCC CZMS (1990) Strategies for adaptation to sea-level rise. Report of the Coastal Zone M anagement Subgroup, IPCC Response Strategies Working Group, Rijkswaterstaat, The Hague

IPCC CZMS (1992) Global climate change and the rising challenge of the sea. Report of the Coastal Zone M anagement Subgroup, IPCC Response Strategies Working Group, Rijkswaterstaat, The Hague

Kelly M P (1991) Global warming: implications for the Thames barrier and associated defences. In: Frasetto R (ed) Impact of sea level rise on cities and regions. Proceedings of the 1st International Meeting 'Cities on Water', Venice, December 1989. Marsilio Editori, Venice, p 93-98

Klein RJT, Nicholls RJ (1998a) Coastal zones. In: Burton I,
Feenstra J F, Parry ML, Smith J B, Tol RSJ (eds) UNEP handbook on methods for climate change impact assessment and adaptation studies, Version 2.1. United Nations Environment Programme and Institute for Environmental Studies, Vrije Universiteit, Amsterdam (in press)

Klein RJ T, Nicholls RJ (1998b) Assessment of coastal vulnerability to sea-level rise. Ambio (in press)

Klein RJT, Smit MJ, Goosen H, Hulsbergen CH (1998) Resilience and vulnerability: coastal dynamics or Dutch dikes? Geogr J 164:259-268

Koster MJ, Hillen R (1995) Combat erosion by law: coastal defence policy for the Netherlands. J Coast Res 11: 1221-1228

Leafe R, Pethick J , Townend I (1998) Realising the benefits of shoreline management. Geogr J 164:282-290

Leatherman SP, Yohe GW (1996) Coastal impact and adaptation assessment. In: Benioff R, Guill S, Lee J (eds) Vulnerability and adaptation assessments - an international handbook, Version 1.1. Kluwer Academic Publishers, Dordrecht, p 5.63-5.76, H.1-H.39

M cLean R, M imura N (eds) (1993) Vulnerability assessment to sea level rise and coastal zone management. Proceedings, IPCC/WCC'93 Eastern Hemisphere Preparatory Workshop, Tsukuba, August 1993. Department of Environment, Sport and Territories, Canberra

Milliman J D, Broadus J M, Gable F (1989) Environmental and economic implications of rising sea level and subsiding deltas: the Nile and Bengal examples. Ambio 18:340-345

Mimura N, Nunn PD (1998) Trends in beach erosion and shoreline protection in rural Fiji. J Coast Res 14:37-46

Mimura N, Isobe M, Hosokawa Y (1994) Impacts of sea-level rise on J apanese coastal zones and response strategies. In: O'Callahan J (ed) Global climate change and the rising challenge of the sea. Proceedings of the 3rd IPCC CZMS workshop, Margarita Island, March 1992. NOAA, Silver Spring, MD, p 329-349

Nicholls RJ (1995a) Coastal megacities and climate change. GeoJ ournal 37:369-379

Nicholls RJ (1995b) Synthesis of vulnerability analysis studies. In: Beukenkamp P (ed) Proceedings of WC C'93. CZM Management Publication No. 4, National Institute for Coastal and Marine M anagement, The Hague, p 181-216

Nicholls RJ , Hoozemans FMJ (1996) The Mediterranean: vulnerability to coastal implications of climate change. Ocean Coast M anage 31:105-132

Nicholls RJ , Leatherman SP (1996) Adapting to sea-level rise: relative sea level trends to 2100 for the USA. Coast M anage 24:301-324

Nicholls RJ, Awosika LF, Niang-Diop I, Dennis KC, French GT (1993) Vulnerability of West Africa to accelerated sealevel rise. In: Coastlines of Western A frica. American Society of Civil Engineers, New York, p 294-308

Nicholls RJ , Mimura N, Topping J (1995) Climate change in South and Southeast Asia: some implications for coastal areas. J Global Environ Eng 1:137-154

Nunn PD, Mimura N (1997) Vulnerability of South Pacific island nations to sea-level rise and climate change. J Coast Res Spec Iss 24:133-151

Nunn PD, Ravuvu AD, Balogh E, M imura N, Yamada K (1994) Assessment of coastal vulnerability and resilience to sealevel rise and climate change, Phase II, Case Study: Savai'i Island, Western Samoa. South Pacific Regional Environment Programme, A pia, Western Samoa

Nunn PD, Aalbersberg W, Clarke WC, Korovulavula I, M imura N, Ohno E, Yamada K, Serizawa M, Nishioka S (1996) Coastal vulnerability and resilience in $\mathrm{Fiji}$, assessment of climate change impacts and adaptation, Phase IV. South Pa- 
cific Environment Programme, A pia, Western Samoa

Parry ML, Carter TR (1998) Climate impact and adaptation assessment-a guide to the IPCC approach. Earthscan Publications, London

Pernetta J C (1992) Impacts of climate change and sea-level rise on small island states: national and international responses. Global Environ Change 2:19-31

Pernetta J C, Milliman J D (eds) (1995) Land-ocean interactions in the coastal zone: implementation plan. IGBP Report No. 33, International Geosphere-Biosphere Programme, Stockholm

Pethick J (1993) Shoreline adjustment and coastal management: physical and biological processes under accelerated sea-level rise. Geogr J 159:162-168

Riebsame WE, Strzepek KM, Wescoat J L, Perritt R, Gaile GL, J acobs J , Leichenko R, Magadza C, Phien $H$, Urbiztondo BJ , Restrepo P, Rose WR, Saleh M, Ti LH, Tucci C, Yates D (1995) Complex river basins. In: Strzepek KM, Smith J B (eds) As climate changes: international impacts and implications. Cambridge University Press, Cambridge, p 57-91

Sem G, Campbell J R, Hay J E, M imura N, Ohno E, Yamada K, Serizawa M, Nishioka S (1996) Coastal vulnerability and resilience in Tuvalu: assessment of climate change impacts and adaptation. South Pacific Regional Environment Programme (SPREP), A pia, Western Samoa

Snedaker SC, Meeder J F, Ross MS, Ford RG (1994) Discussion of Ellison and Stoddart, 1991. J Coast Res 10:497-498

Sterr H, Simmering F (1996) Die Kuestenregionen im 21 Jahrhundert. In: Sterr H, Preu C (eds) Beitraege zur aktuellen Kuestenforschung. Vechtaer Studien zur Angewandten Geographie und Regionalwissenschaft (VSAG), Nr. 18, p 181-188

Stevenson J C, Ward LG, Kearney MS (1986) Vertical accretion in marshes with varying rates of sea-level rise. In: Wolfe DA (ed) Estuarine variability. Academic Press, New York, p 241-259

Strzepek KM , Smith J B (eds) (1995) As climate changes: international impacts and implications. Cambridge University Press, Cambridge

Titus J G (1998) Rising seas, coastal erosion and the takings clause: how to save wetlands and beaches without hurting property owners. Maryland Law Rev 57:1279-1395

Titus J G, Narayanan V (1996) The risk of sea-level rise: a delphic Monte Carlo analysis in which twenty researchers specify subjective probability distributions for model coefficients within their respective areas of expertise. Clim Change 33:151-212

Titus J G, Park RA, Leatherman SP, Weggel J R, Greene MS, Mausel PW, Brown S, Gaunt C, Trehan M, Yohe G (1991) Greenhouse effect and sea level rise: potential loss of land and the cost of holding back the sea. Coast Manage 19: $171-204$

Toms G, Hoozemans FMJ , Zeidler RB, Huan NN (1996) Vietnam coastal zone vulnerability assessment. First steps towards integrated coastal zone management. Final Report. Government of the Socialist Republic of Vietnam and Government of The N etherlands
Tooley MJ , J elgersma S (eds) (1992) Impacts of sea-level rise on European coastal lowlands. Blackwell, Oxford

Tsyban A, Everett JT, Titus J G (1990) World oceans and coastal zones. In: McTegart WJ, Sheldon GW, Griffiths DC (eds) Climate change: the IPCC impacts assessment. Australian Government Publishing Service, Canberra, p 6.1-6.28

Turner RK, Doktor P, Adger WN (1995) Assessing the costs of sea-level rise. Environ Planning A 27:1777-1796

UK Department of the Environment (1996) Review of the potential effects of climate change in the United Kingdom. HMSO, London

UK M inistry of Agriculture, Fisheries and Food, Welsh Office, Association of District Councils, English Nature, National Rivers Authority (1995) Shoreline management plans: a guide for coastal defence authorities. Ministry of Agriculture Fisheries and Food, London

UN Population Division (1993) World urbanized prospects 1992. United Nations Population Division, New York

Warrick RA, Ahmad QK (eds) (1996) The implications of climate and sea-level change for Bangladesh. Kluwer Academic Publishers, Dordrecht

Warrick RA, Oerlemans J (1990) Sea-level rise. In: Houghton JT, J enkins GJ, Ephramus JJ (eds) Climate change: the IPCC scientific assessment. Cambridge University Press, Cambridge, p 257-281

Warrick RA, Oerlemans J, Woodworth PL, Meier MF, le Provost C (1996) Changes in sea level. In: Houghton JT, Meira Filho LG, Callander BA (eds) Climate change 1995: the science of climate change. Cambridge University Press, Cambridge, p 359-405

Watson RT, Zinyowera M C, M oss RH, Dokken DJ (eds) (1998) Regional impacts of climate change: an assessment of vulnerability. Cambridge University Press, Cambridge

WCC'93 (1994) Preparing to meet the coastal challenges of the 21st century. World Coast Conference Report, Noordwijk, November 1993, Rijkswaterstaat, The Hague

Wigley TML (1995) Global-mean temperature and sea level consequences of greenhouse gas stabilization. Geophys Res Lett 22:45-48

Wigley TML, Raper SCB (1992) Implications for climate and sea level of revised IPCC emissions scenarios. Nature 357: 293-300

World Bank (1997) Caribbean: planning for adaptation to global climate change. Project document prepared by the World Bank and the Organization of American States for the Global Environment Facility, J anuary, 1997, Washington, DC

Yamada K, Nunn PD, Mimura N, Machida S, Yamamoto M (1995) M ethodology for the assessment of vulnerability of South Pacific island countries to sea-level rise and climate change. J Global Environ Eng 1:101-125

Yim W (1995) Implications of sea-level rise for Victoria Harbour, Hong Kong. J Coast Res Spec Iss 14:167-189

Zeidler RB (1997) Climate change variability and response strategies for the coastal zones of Poland. Clim Change 36: 151-173 